embryological and anatomical studies on Cladocera and Conchostraca, but in 1926 he published a paper on the feeding of an ostracod, Pionocypris, which was the first of a long series of detailed investigations into the complex filtratory feeding mechanisms found in a wide range of Crustacea. He recognized clearly the essential functional components of these mechanisms, describing current producing, filtering, scraping, and transporting limbs, and illustrated them with minute accuracy. The small size of many of these animals, and the difficulty of direct observation of feeding currents, compelled him to rely in large measure on deduction based on the details of structure. His strong interest in functional morphology generally clearly arises from these researches. Papers on feeding mechanisms were followed by a return to internal anatomy, and outstanding papers were those on the ostracods Doloria and Gigantocypris and the cirripede Lithotrya. In spite of the injuries to his wrists, Cannon showed great skill in fine dissection, and became a zoological artist of distinction. His early papers show the steady development of his technique, and by 1930 his illustrations could truly be described as unequalled. Furthermore, he had the ability to communicate his skill to others, and zoologists generally profited greatly by his publication of a book on methods of drawing and illustration.

In 1948 Graham Cannon was president of Section D (Zoology) of the British Association for the Advancement of Science, and his presidential address on undergraduate zoology marked the beginning of a new interest. From this time on he frequently wrote and spoke on educational matters, and rebelled against increasing specialization in teaching in schools and universities. $\mathrm{He}$ turned this interest to practical account by serving on the Northern Universities Joint Matriculation Board, and played an active part in the development of the University of Keele.

Towards the end of his life Cannon became increasingly occupied with thinking and writing on the relationship betwoen Lamarckian and Mendelian inheritance, an interest which clearly had its origin in his work on crustacean feeding mechanisms. He came to hold the view that tho fundamental property of protoplasm is its ability to adjust itself to changes in the environment always in the manner optimum to its survival, and that inheritance by the mechanism of the Mendelian gene complex was to be regarded as a later addition to this fundamental property.

In addition to his research and teaching, Graham Cannon played a full part in University administration. He undertook in Manchester periods of office as dean of the Faculty of Science and as pro-vice-chancellor, and was for many years chairman of the Manchester Museum. Ho served on the Council of the Marine Biological Association, and was well known as an examiner in the University of London. His range of interests was wide, and embraced such diverse interests as music, angling in his early years, cookery, and practical building. But his overriding passion was his love of Japanese objects of art, particularly swords and their furnishings. He was always ready to talk on this topic, publicly or privately, with enthusiasm and understanding.

As a man, Graham Cannon was direct in speech and expressed his views forcibly. He did not easily accept compromise. But thoso who knew him well saw a genial and kindly scholar who took a real interest in his students and staff. They will remember him with gratitude and affection. Their sympathy and that of his friends will go out to his wife and sons and daughters. R. DenNelL

\section{Mr. A. D. Cotton, O.B.E.}

Arthur Disbrowe Cotton, who for nearly sixty years was closely connected with the affairs of the Royal Botanic Gardens, Kew, died, after a long spell of ailing health, at Hertford, on December 27, 1962, at the age of eighty-three. He was born in London on January 15 ,
1879, and received his early education at King's College School, London. During his schoolboy days he developed a strong interest in the British flora, and he built up a considerable collection of pressed plants. His first botanical tuition was received from lectures arranged at Chelsea Physic Garden by J. B. Farmer, and these may well have fostered his liking for gardens and garden plants, an attachment which remained and indeed increased throughout his career. At one time Cotton seems to have determined on a career in horticulture, and he undertook three years' practical training which led to a first-class certificate in the Royal Horticultural Society's general examination.

Later, he decided to follow botany as a vocation, and to this end he spent three years at the Royal College of Science, London, where, under the influence of J. B. Farmer, he specialized in the study of the lower plants. In 1902 he obtained his first post at Owens College, Manchester, where he became an assistant lecturer and, under the influence of $O$. V. Darbyshire, became interested in fungi and did some research on orchid mycorrhiza. 'Two years later he entered Government service as an assistant in the Herbarium at Kew under George Massee, the distinguished mycologist. His general duties and research were mainly concerned with the algae, but he also worked with the fungi and lichens, and during this period he published several papers on these groups including his very important contribution to algal ecology in the Clare Island Survey. In 1915, Cotton was placed in charge of advisory services and research on plant diseases in a new laboratory installed at Kew, and indeed he was the first plant pathologist to be appointed in Government service in Great Britain. The laboratory which he initiatod was later transferred to Harpenden and has become the Plant Pathology Laboratory of the Ministry of Agriculture, Fisheries and Food. Cotton's continuing interest in mycology is reflected in his sixty years' membership of the British Mycological Society of which he was president in 1913.

Cotton returned to Kew in 1922 when he succeeded Otto Stapf as the keeper of the Herbarium and Library, a post he held until his retirement in 1946. This was a period of active development in the Herbarium with an ever-increasing flow of material to be identified, incorporated and distributed, and about a million specimens were added to the collections during Cotton's keepership. While he retained his interest in the algae and fungi, he turned more to the study of flowering plants. He became an expert on the cultivated lilies, published a number of papers on this attractive group, and largely wrote the botanical text of the Supplement to Elwes' Monograph of the Genus Lilium of which latterly he was joint author. For a short timo he was editor of Curtis's Botanical Magazine, and for this and other services to horticulture he was awarded the Victoria Medal of Honour by the Royal Horticultural Society. Cotton attended the meeting of the British Association in South Africa in 1929 and during his return journey visited Kilimanjaro. The extraordinarily bizarre vegetation of the alpine slopes fired a new interest and he undertook a critical study of the arborescent species of Senecio of the East African mountains. One species which he collected on Kilimanjaro bears his name.

He became a Fellow of the Linnean Society in 1902 , served for several periods on the Council and was president during 1943-46. In 1934 he was awarded an O.B.E. Cotton was a man of gentle, unassuming manner who will be remembered gratefully by all who had the pleasure of his friendship as a genial, kind and obliging man.

George Taylor

\section{Prof. Karel Hrubý}

Prof. Karel Hrubý, professor of geneties in the Charles University in Prague, died in a motor-car accident in Jihlava on December 10, 1962. He was one 
of the few outstanding Mendelian geneticists in eastern Europe.

Karel Hrubý was born in Prague on September 30, 1910. $\mathrm{H}_{\theta}$ received all his education in that city, studying genetics at the Charles University under Prof. B. Nermec and Prof. A. Brožek. In order to broaden his genetical outlook. he worked for eight months as a Rockefoller Fellow at the John Innes Horticultural Institution in London in 1938; this greatly influenced all his later work and strengthened his regard for classical genetics when the Lysenko wind became most severe. After the Second World War he again visited Britain, this time on invitation by the British Council, to study the progress of genetics in the Western World during tho War. He participated in the genotics congresses in Stockholm (1948) and Montreal (1958), and was at his death member of the Genotical Section of the International Union of Biological Sciences.

Prof. Hrubý lectured in genetics at the Charles Univer. sity, at which he succeeded Prof. Brožek, first as docent, in 1937, and later as professor, in 1945. He also lectured in his subject for some time after the War at Brno and Bratislava, but otherwise all his active academic life was spent at his own Alma Matei.

Prof. Hrubý was an ardent worker in different fields of geneties, in animals and plants and even humans, but he also made significant contributions to the taxonorny of certain plant groups. He was the author of about 170 papers. In addition, he published four books which were widely distributed in his own country. The last of these. Genetika, published in 1961 , is a masterly treatment of classical and modern Mendelian cytogeneties, the only rocent publication of its kind in the Soviet part of the world. Naturally, it is widely used in academic teaching in Czochoslovakia and neighbouring countries, and it is being translated into Russian.

Though very active in scientific research and academic teaching, Prof. Hrubý also found time to take part in many outside activities. At his death he was a member of scientific committees of several academic and practical institutions, on the editorial staff of several journals and the editor of the horticultural publications of the Czechoslovak Academy of Sciences. $H_{\Theta}$ was also president of the large Czechoslovak Botanical Society and the chiof organizer of its very successful symposium on experimental taxonomy held at its fiftieth anniversary jubilee meeting in July 1962, with several hundred participants from home and abroad.

Prof. Hrubý is survived by his wife, Anna, a son and four daughters. He is remembered as an energetic supporter of scientific cytogeneties during times of bureaucratic suppression of Mendelian ideas, as a scientist of unusual ability, but above all for his character and personality and untiring helpfulness to others.

Áskeli, Löve

\section{Dr. Thomas Bedford, O.B.E.}

Dr. Thomas Bedford diod on January 24 in his sixty-ninth year. His sudden passing will have come as a great shock to a wide circle of friends and colleagues.

Dr. Bedford had been engaged on problems of occupational hygiene for the past 44 yeurs, and he will rank as one of the pioneers in this important field. He was appointed to the staff of the then Industrial Fatigue Research Board in January 1919. A year later he joined forces with the late Dr. H. M. Vornon, and their conjoint working continued until the latter's retirement in 1933. During this period a wide range of investigations were eoncerned with problems relating to rest pauses and accident rates in many industries, and the influence of atmospheric conditions on the working capacity and the comfort of workers was also studied.

From 1933 Dr. Bedford began to specializo in the field of thormal studies. His rosearches into the physiological reactions of the human being to thermal strosses establishod basic principles and methods of measurement and evaluation which became accepted as standard practice internationally. As director of the Environmental Hygiene Research Unit of the Medical Research Council ho attained great eminence and became an outstanding authority in his particular field. In 1953, by which time Dr. Bedford had long felt that a society should exist in Great Britain to represent those engaged in the field of occupational hygiene, his personal effort and enthusiasm were responsible for the founding of the British Occupational Hygiene Society. This now flourishing body will continue to be a fitting tribute to his memory. Although he retired from the service of the Modical Research Council in 1959, when he was awarded an O.B.E., Dr. Bedford maintained his many contacts on Government and other official committees. Personally, Tom Bedford was of a quiet and unassuming nature. His dedication to work was always blended with qualitios of marked benevolence and kindness that endeared him to all who had the good fortune to be associated with him, privately and professionally. Many will remember with gratitude the help that he gave them so generously in dealing with their problems.

So has ended a full life of distinguished contribution to the science of occupational hygiene. in which Tom Bedford's guiding principle was always service before self.

C. (4. WARNER

\section{NEWS and VIEWS}

\section{Deputy Principal at the University of Birmingham:}

Dr. T. Alty

Dr. Thomas Alty, retiring vice-chancellor of Rhodes University, South Africa, has been appointed deputy principal of the University of Birmingham as from May 8. Dr. Alty was appointed master of Rhodes University College in 1948 and became first principal and vice. chancellor of Rhodes University on its establishment in 1951. Dr. Alty was educated at the University of Liverpool, where he was Oliver Lodge Fellow in 1921, and at the University of Cambridge. Ho was a lecturer in physies at the University of Durham from 1924 until 1925. and in 1925 was appointed to the chair of physics at the University of Saskatchowan, Canada. He held this chair until 1932 when he wes appointed research professor of physies in the same University. In 1935 he returned to Britain when he was appointed to the Cargill chair of applied physics at the University of Glasgow. This he held until 1945 and thereafter the Cargill Chair of Natural Philosophy in the same University until 1948. From 1958 until $1960 \mathrm{Dr}$. Alty was chairman of the Association of Universities of the British Commonwealth. From the date of Dr. Alty's appointment as deputy principal the office of vice-principal will bo known as the offier of pro-vice-chancellor and vice-principel.

\section{Electronic Engineering at Leeds:}

Prof. P. J. B. Clarricoats

Dr. P. J. B. Clakricoats has been appointed professor of electronic engineering in the University of Leeds. He 